\title{
Examining HRM Practices in Relation to the Retention and Commitment of Talented Employees
}

\author{
Juraj Tej, Matúš Vagaš, Viktória Ali Taha *D, Veronika Škerháková (D) and Michaela Harničárová
}

Faculty of Management, University of Prešov, 08001 Prešov, Slovakia; juraj.tej@unipo.sk (J.T.); matus.vagas@smail.unipo.sk (M.V.); veronika.skerhakova@unipo.sk (V.Š.); michaela.sirkova@unipo.sk (M.H.)

* Correspondence: viktoria.ali-taha@unipo.sk

check for updates

Citation: Tej, J.; Vagaš, M.; Ali Taha, V.; Škerháková, V.; Harničárová, M. Examining HRM Practices in Relation to the Retention and Commitment of Talented Employees. Sustainability 2021, 13, 13923. https://doi.org/ $10.3390 /$ su132413923

Academic Editors: Amelia Manuti, Antonino Callea and Maria Luisa Giancaspro

Received: 6 November 2021 Accepted: 13 December 2021 Published: 16 December 2021

Publisher's Note: MDPI stays neutral with regard to jurisdictional claims in published maps and institutional affiliations.

Copyright: (c) 2021 by the authors. Licensee MDPI, Basel, Switzerland. This article is an open access article distributed under the terms and conditions of the Creative Commons Attribution (CC BY) license (https:// creativecommons.org/licenses/by/ $4.0 /)$.

\begin{abstract}
The claim that human resources or human capital is the most important and valuable asset of organizations is widespread and widely accepted. For this reason, one of the biggest challenges for organizations is to find the right employees with the necessary skills, high potential, and talent. However, the challenge for organizations is not only to find, but also to retain and to use the potential of talented employees. The main aim of this study is to identify the HRM practices which most significantly affect the retention and commitment of talented employees. Based on factor analysis, individual factors of HRM practices were identified. Through canonical analysis, the relationships between the identified factors of HRM practices, talent retention (the intention of talented employees to remain in the organization), and the organizational commitment of talented employees were identified. One of the most important results of the study is the identification of human resource management practices that are most strongly associated with talent retention and commitment.
\end{abstract}

Keywords: talented employees; HRM practices; organizational commitment; retention

\section{Introduction}

In today's highly competitive and dynamically changing business environment, talented employees are considered a key factor in the differentiation, success, and sustainable development of organizations. The need for talent management is underlined by the fact that organizations are facing a growing skills gap and the lack of high-quality candidates to fill the open positions. The concept of talent management is a relatively new concept that began to emerge in the 1990s. It covers a wide range of processes and practices, particularly the planning, identification, recruitment and selection, training and development, retention, and remuneration of talented people. According to Cappelli, talent management is a matter of anticipating the need for human capital and then setting a plan to meet it [1]. The goal of talent management is to attract, identify, develop, engage, retain, and place high-potential individuals, who are perceived as extremely valuable and precious to the organization. Through talent management, organizations can create high-performing workplaces, encourage learning organizations, strengthen the employer brand, and improve diversity management [2]. Its essence is to ensure the development and career advancement of highly talented and qualified individuals in the organization through formalized procedures, resources, policies, and processes. Due to the shortage of talents and the relatively high number of opportunities for these talented individuals to find a job, organizations must make an enormous effort in order to retain talent and ensure their commitment. In addition to the fact that human resource management practices affect the retention and organizational commitment of talented employees, there is also an interconnection between retention and organizational commitment. Based on the job embeddedness theory, it has been proven that individuals who are more embedded in their organizations are more likely to stay in their jobs [3]. That is why in our study, we aimed to identify an appropriate set of human resource management practices, with an emphasis on talented employees, 
that have the effect of reducing talent turnover (i.e., retaining talented employees) and increasing commitment, and which can be useful for both researchers and practitioners.

\section{Literature Review}

Human resources, especially talented employees, are a crucial factor for business success. According Chartered Institute of Personnel and Development (CIPD), talents are "individuals who can make a significant difference to organizational performance. This may either be through their immediate contribution or, in the longer-term, by reaching their highest levels of potential" [2]. Green identified nine key processes that are typically part of talent management programs: compensation and rewards, engagement, high-potential employee development, individual professional development, leadership development, education and training, performance management, recruitment, and planning succession [4]. Of particular importance are talent identification, recruitment, retention, and development.

The problem that many organizations struggle with is the high turnover of talented employees. They need to implement HRM practices that ensure the loyalty and commitment of talented employees. As mentioned, one of the main responsibilities of the HR department in changing the business environment is to secure and retain the talents [5]. In his study, Kumar investigated the relationship between talent management practices and employee retention intentions (that is, employee turnover) [5]. Based on the assumption that employees' retention intentions are associated with four talent management practicesrecruitment and selection, performance and career management, salary and compensation, team and management support - the author found compensation (rewards and incentives) and performance management (training, development and growth opportunities, and career paths) to be the most influential factors for employee retention [5].

The aim of the study of Haldorai et al. [6] was to investigate the turnover intentions of hotel employees using the pull-push-mooring framework. Among the eight push factors that were expected to have a positive relationship with the turnover intentions, the relationship was demonstrated by six factors, namely work overload, low career progression, interpersonal tension, emotional labor, work interference with personal life, and personal life interference with work. Among the five pull factors (that were expected to be negatively related to turnover intention), two factors seemed to be the most influential-community fit and travel opportunities. The authors also assumed that the mooring variable (personal life involvement) would moderate the link between work interfering with personal life/personal life interfering with work and the turnover intention, but this moderation effect was significant only in the medium-term turnover intention. Based on this study, Mutanga et al. [7], in their research carried out in Namibia, explored some of the key push and pull factors necessary for the provision of opportunities for talent development and retention. In order to mitigate the push factors, talent retention strategies, such as the promotion of a conducive working environment, cognitive engagement, career advancement opportunities, and offering competitive salaries, would have to be implemented. Among the pull factors, better salary, job security, growth and advancement prospects, conducive work environment, work flexibility, work perks, and mentally challenging jobs seemed to be the most influential variables that encourage employees' retention. The workforce retention rate is also associated with workplace culture, which is one of the most influential factors of employee commitment, engagement, and job satisfaction [8].

Appropriately chosen human resource management practices are the key to retaining talented employees. HRM practices should be based on up-to-date analyses of the needs of the organization and its employees. There are a number of HRM practices that are functional and effectively influence talented employees. The author of the well-known concept of human resource management practices, Jeffrey Pfeffer [9], compiled a set of HRM practices that have been reduced, innovated, and improved over time in relation to the economy and the labor market. Miao et al. [10] emphasized that well-chosen HRM practices should expand the knowledge and skills of individuals as well as support them in thinking and solving problems. Human resource management should use practices 
that increase the emotional attachment of employees to their organizations, create a sense of moral obligation to remain in the company, which in turn increases the organizational commitment of employees [11].

Various studies have revealed that the way human resources are managed and leadership style have a direct impact on the ability to maintain/retain an existing workforce [12]. Creating an organizational environment aimed at retaining talented staff is the first step in reducing employee turnover. Identifying the reasons why employees leave the organization is an important part of developing an effective human resource management strategy. One way to obtain this information is to conduct in-depth interviews with outgoing staff. Knight's study [13] showed that the main reasons for employees leaving organizations (with a high turnover rate) are: work stress, insufficient staffing, lower support, communication, and cooperation in the organization. Based on the above, it is possible to assume the existence of a statistically significant relationship between a set of human resource management practices and the retention of talented employees in organizations. The following hypothesis was formulated:

Hypothesis 1. There is a statistically significant relationship between a set of human resource management practices and retaining talented employees in organizations.

Formally setting up the second hypothesis was determined by the fact that several studies and research have revealed that there is a statistically significant relationship between organizational commitment and retention [14]. As for retention, the goal of organizations is to achieve the highest possible level of organizational commitment from their employees because it is closely related to employees' satisfaction, engagement, productivity, and job performance, which in turn leads to better organizational performance and results. Organizational commitment can be defined as an employee's attachment to his/her workplace or a degree of the employee's identification with and involvement in a company [15]. The essence of organizational commitment is an affective attachment of an employee to the organization [16], his/her identification with the organization [17], or his/her identification with and involvement in the organization [18]. According Allen and Meyer [19], organizational commitment is a psychological situation that binds an employee to an organization, which will positively influence an employee to remain with an organization.

The relationship between employee and organization has been recognized as a social exchange relationship. In this context, organizational commitment is a behavior developed while the process of such exchange relationship is established [20]. In this spirit, many organizations and companies strive to maintain a competitive advantage based on a social exchange that strengthens the organizational commitment of employees. Based on the social exchange theory, Eisenberger et al. [21] argued that "employees tend to regard an organization as a person and form a global belief regarding how this personified organization recognizes their contribution and cares for their well-being". If an employee perceives his/her organization to be supportive, he/she tends to reciprocate the organizations' supportiveness with increased commitment. Moreover, this perceived organizational support is strongly affected by organizational practices and policies such as pay, job enrichment, and participation [22].

The essence of commitment is positive evaluation and a sense of responsibility that an employee has regarding his or her organization [23]. Employee commitment manifests itself through employees' attitudes and behaviors and other organizational outcomes such as job satisfaction, affective commitment, and retention levels [24], overall degree of employees' identification, involvement, and loyalty towards the company [25]. Organizational commitment was defined by Greenberg and Baron [26] as the degree to which employees identify with the organization, the degree of commitment they show, and the willingness to leave it. There are basically three main perspectives in research related to organizational commitment: (1) the first perspective is based on the perspective of social exchange, according to which the commitment of the employee toward the organization 
is the result of the small investments that he/she has made over time [27]; (2) the second perspective is represented by Affective Commitment, with an emphasis on the binding force between the person and the organization, which is characterized by the employee's desire to remain in the organization, accepting organizational values and goals in return for certain psychological rewards such as support or recognition [28,29]; (3) the third perspective, represented by the Normative Commitment developed by Meyer and Allen [30], is focused on the work ethic and the responsibility that an employee acquires, which drives him/her to do his/her job well in any circumstance.

At present, the relationship between human resource management practices and employee commitment is being widely studied. Previous studies and research on employee loyalty have shown a rapid decline in loyalty in relation to the current and future market situation [31,32]. Among high-commitment HRM practices are common practices such as enriched job design, team-based approach, participation in decision making, pay for performance, high level of pay, accurate performance appraisal, extensive training and development, and selective staffing (Appelbaum et al. 2000; Arthur 1994; Delery and Shaw 2001; Guest 1997; Huselid 1995; Pfeffer 1998; Whitener 2001; Wright et al. 2003, in [22]). The study by Rhoades et al. [33] revealed that factors such as organizational rewards, procedural justice, and supervisor support are an expression of perceived organizational support and can thus strengthen commitment [18]. Based on the assumptions that (1) employees with the perception of receiving support from their managers in their development are more likely to be engaged with the organization [34] and (2) effective coaching can enhance employees' feelings of competence, which leads to employees' organizational commitment [35]. Park, McLean, and Yang [36] revealed in their study that managers' coaching skills impact employees' personal learning, and managerial coaching impacts employees' organizational commitment. The study of Ji and Jan [37], which was focused on interpersonal trust, i.e. trust in supervisor and in coworker (both of which have the potential to affect employees' job satisfaction, organizational commitment, organizational citizenship behavior, cooperation, and overall performance), revealed that supervisor support leads to frontline employees' trust in their supervisor, while abusive supervision significantly decreased employees' trust in their supervisor. Furthermore, building on the research and studies of the time, Macky, D'Amato and Herzfeldt [38] concluded that learning in organizations is also related to organizational commitment and the intention to remain with the organization. Revuelto-Taboada, Canet-Giner, and Balbastre-Benavent [39] emphasized the key role of human resource management in addressing the new challenges that companies currently face in order to achieve the required competitiveness and sustainability in a growing market. The results of this study pointed to individual positive interactions of human resource management practices that support the implementation of socially responsible organizational initiatives by organizations. In the context of the above, we assumed that there is a statistically significant relationship between a set of human resource management practices and the commitment of talented employees; thus, the following hypothesis was formulated:

Hypothesis 2. There is a statistically significant relationship between a set of human resource management practices and the commitment of talented employees.

\section{Materials and Methods}

The aim of this study was to identify the individual HRM practices that significantly affect the retention and organizational commitment of talented employees in the company. The primary data were obtained through a self-administered questionnaire during the second wave of the COVID-19 pandemic (February 2021) in the Slovak Republic. The questionnaire contained 50 questions identifying a set of HRM practices applied in companies [40-42]. The questionnaire survey was aimed at obtaining data on the degree of organizational commitment of talented employees (through a set of 15 questions developed by Mowday, Steers, and Porter [28]), and the retention of talented employees (with 
18 questions taken from Newstrom [42]; Judge [43]; Lindsey and Kleiner [44]). The level of agreement with the individual items was assessed by using the five-point Likert scale: (1) Strongly disagree; (2) Disagree; (3) Neither agree nor disagree; (4) Agree; (5) Strongly agree. The questionnaire was distributed online to 360 randomly selected manufacturing companies employing more than 50 employees. The main source for obtaining information about Slovak organizations was the Slovak Entrepreneur Index database, from which the 5371 companies employing more than 50 employees were generated. The target population consisted of all employees who had been designated as organizational talents by the organizations, regardless of the position they held. The sample frame was a subset of talented employees working in randomly selected companies to whom we had access. Individual organizations were approached with a request to distribute the questionnaire among employees who were considered/identified to be organizational talents. As the questionnaire was anonymous, it was not possible to unambiguously identify the rate of return from the individual organizations contacted. The research sample consisted of 391 talented employees who had been identified by their supervisors and HR managers in companies and subsequently approached to participate in the research. Statistical software Statistica and MS Excel were used to process the obtained data. To verify individual hypotheses, validated methods such as the Kaiser-Mayer-Olkin test, Bartlett's Test of Sphericity, PCA analysis, and Canonical correlation analysis were applied.

There are different approaches to proposing human resource management practices. Martín-Alcázar et al. [45] summarized the theoretical basis of human resource management models into three different approaches, with each approach emphasizing its own specific dimension in strategic human resource management. The individual models provide a systematic overview of the perspectives which organizations should follow when they choose a specific model. Universalistic perspective: This is the simplest approach to the analysis of human resource management strategies. This model seeks the best way to manage people so that the organization's goals are met as effectively as possible. In terms of the level of analysis, the universalistic model focuses mainly on the sub-functional point of view, analyzing how individual and isolated human resource policies are linked to organizational performance [40]. Although the literature has pointed out many best human resource management practices (remuneration, recruitment and selection of employees, performance evaluation), it is possible to identify topics that emerge repeatedly, which, in general terms, represent the core of the universalistic contribution [46]. Contingency perspective: The contingent model introduces a different starting assumption in relation to what the relationship between variables means. Contrary to the linearity argued by the universalists, they propose a model based on interactivity. The relationship between the dependent and the independent variables will no longer be stable, and it will vary depending on other third variables (size of the organization, sector, nature of work, etc.). These factors deny the existence of proven approaches that could lead to higher performance in all circumstances, using a contingent management approach. With regard to the contingent approach to management, researchers accept the view that the stronger and greater the consistency between business strategy and SALW practices, the greater the impact of the practices on performance [40]. Configurational perspective: The configurational perspective contributes to the explanation of SHRM, with a useful insight into the internal aspects of the function by means of the analysis of the synergic integration of the elements that build it [46]. Sojka [47] notes that this model faces multilateral criticism because it simplifies what cannot be simplified in practice. The contingency management model determines that in an effort to assign an external variable to another internal variable, a linear relationship without complications is assumed.

It is extremely unlikely that no complication will occur, as organizations in today's competitive market need to respond promptly to changes in the external environment not only in terms of strategy, but also in terms of communication to achieve more effective performance. Based on the above, it can be stated that companies should strive to create an integrated model of human resource practices that would be able to cover both vertical 
and horizontal integration while addressing the buffer effect of possible human resource risks at the same time.

Marchington and Grugulis [48] discussed how Pfeffer's model of human resource management practices has been modified since the end of the 20th century and slimmed down to those practices which are considered the best and most important. Many authors from abroad have tried (not only on a theoretical basis, but also in studies and papers) to analyze and identify those practices that, from a practical point of view, could be the most beneficial and universal for organizations. The authors considered the human resource management practices as a specific set that, if properly implemented, can increase the organization's profits.

Given the facts above, the possible differences that arise in terms of time as well as the possible differences in the definition of individual practices in terms of geographical location, we chose the exploratory factor analysis as an underlying tool. We therefore assumed that the research tool, which contained 50 items, had to be explained by a group of common latent variables defined as human resource management practices. The implemented exploratory analysis thus suited the research in terms of methodology. In terms of defining the method of extraction of common latent variables, the principal components method met the condition of maximizing the explained variance and at the same time minimizing residual correlations. The research problem could be approached differently. However, the results of the exploratory analysis only provided basic baseline results and the proposed factor model was subsequently verified on a new group of respondents using a confirmatory factor analysis. To that end, the results and relationships between individual endogenous and exogenous variables were refined. However, the results of this part of the research could not be published due to the scope of this study.

\section{Results}

The first step was to verify the internal factor structure of the proposed methodology for evaluating HRM practices. We analyzed the respondents' degree of agreement with statements concerning 50 different HRM practices on the five-point Likert scale (from strongly disagree to strongly agree). The list of the analyzed HRM practices (in the form of statements) is presented in Table 1.

Table 1. List of HRM practices.

\begin{tabular}{cl}
\hline \multicolumn{1}{c}{ Item } & \multicolumn{1}{c}{ HRM Practice } \\
\hline I-1 & $\begin{array}{l}\text { My organization makes every effort to align a talented employee with a role that suits them, i.e., it puts the } \\
\text { right people in the right jobs. } \\
\text { I-2 }\end{array}$ \\
My organization has an attractive Employee Value Proposition (EVP = what employees get for what they give) \\
that helps to secure the best talents. \\
My organization makes considerable efforts to find talented employees that fit the organization's culture and \\
core values. \\
I-4
\end{tabular}


Table 1. Cont.

\begin{tabular}{|c|c|}
\hline Item & HRM Practice \\
\hline $\mathrm{I}-13$ & $\begin{array}{l}\text { My organization implements learning programs that include activities and tasks that support the } \\
\text { organization's culture and initiatives. }\end{array}$ \\
\hline $\mathrm{I}-14$ & $\begin{array}{l}\text { Learning and training are aligned with the employee development plan and the roles where particular } \\
\text { employees could move to in the future. }\end{array}$ \\
\hline $\mathrm{I}-15$ & $\begin{array}{l}\text { My organization uses a tailored approach to learning and development so an employee can build a program } \\
\text { that meets his/her needs. }\end{array}$ \\
\hline $\mathrm{I}-16$ & My organization's employees have relative job security, i.e., they have a guaranteed job for the future. \\
\hline $\mathrm{I}-17$ & Any planned changes concerning the redundancies in my organization are announced in due time. \\
\hline $\mathrm{I}-18$ & My organization guarantees job security to employees with a high work commitment and performance. \\
\hline $\mathrm{I}-19$ & Employees in my organization are involved in decisions that management make. \\
\hline $\mathrm{I}-20$ & My organization builds trust between employees and senior management. \\
\hline $\mathrm{I}-21$ & My organization respectfully relates with all employees at all levels. \\
\hline $\mathrm{I}-22$ & $\begin{array}{l}\text { Organization's performance evaluation system is effective, i.e., it has standardized evaluation forms, } \\
\text { performance measures, feedback guidelines, and disciplinary procedures. }\end{array}$ \\
\hline $\mathrm{I}-23$ & Employees' performance evaluations are conducted fairly, consistently, and objectively. \\
\hline $\mathrm{I}-24$ & Managers and/or supervisors who conduct evaluations give employees feedback about their performance. \\
\hline $\mathrm{I}-25$ & Organizational and supervisory support is provided to the organization's employees. \\
\hline $\mathrm{I}-26$ & My organization fully empowers employees to make decisions and resolve problems related to their work. \\
\hline $\mathrm{I}-27$ & My organization supports and reinforces team work and mutual cooperation. \\
\hline $\mathrm{I}-28$ & In my organization, the emphasis is on diversity and inclusion. \\
\hline $\mathrm{I}-29$ & $\begin{array}{l}\text { My organization encourages the exchange of knowledge, skill, information, and experience through social } \\
\text { interaction among employees. }\end{array}$ \\
\hline $\mathrm{I}-30$ & Employees in my organization are clear about where they stand and know what is expected of them. \\
\hline $\mathrm{I}-31$ & My organization creates career paths and challenging job opportunities for employees. \\
\hline I-32 & $\begin{array}{l}\text { My organization provides employees with the opportunity to evaluate their own performance and includes } \\
\text { this information in their performance appraisals. }\end{array}$ \\
\hline $\mathrm{I}-33$ & My organization provides flexible work options. \\
\hline $\mathrm{I}-34$ & $\begin{array}{l}\text { My organization provides suitable physical and procedural work conditions, the comfort and safety of the } \\
\text { workplace, and the reliability of equipment. }\end{array}$ \\
\hline I-35 & $\begin{array}{l}\text { The career development path gives employees a chance to enhance their skills and knowledge that will } \\
\text { potentially allow them to hold higher positions in the future. }\end{array}$ \\
\hline I-36 & $\begin{array}{l}\text { My organization considers employee health by providing an environment that is free from health hazards, } \\
\text { offers a level of privacy, noise control, and also takes into account the individual needs of each employee. }\end{array}$ \\
\hline $\mathrm{I}-37$ & My organization supports and encourages independent and creative thinking. \\
\hline $\mathrm{I}-38$ & $\begin{array}{l}\text { My organization enables talented employees to find ways of harnessing the capabilities of new tools and to } \\
\text { solve problems or come up with original ideas. }\end{array}$ \\
\hline I-39 & My organization has a truly well-rounded and attractive benefits program that is motivating for employees. \\
\hline $\mathrm{I}-40$ & My organization has a strong employer brand and reputation (employer of choice). \\
\hline $\mathrm{I}-41$ & My organization makes talented employees feel valued. \\
\hline $\mathrm{I}-42$ & $\begin{array}{l}\text { My organization implements succession planning (activities aimed at ensuring that it will optimally use their } \\
\text { talented employees by facilitating their flow into the right jobs). }\end{array}$ \\
\hline $\mathrm{I}-43$ & Employees in my organization are fairly treated by supervisors. \\
\hline $\mathrm{I}-44$ & $\begin{array}{l}\text { My organization conducts exit interviews to understand why talented and valued employees decide to leave } \\
\text { the organization. }\end{array}$ \\
\hline $\mathrm{I}-45$ & $\begin{array}{l}\text { My organization conducts, on a regular basis, performance development planning discussions that focus on } \\
\text { the employee's interests for career development. }\end{array}$ \\
\hline $\mathrm{I}-46$ & $\begin{array}{l}\text { Mentoring communication, hands-on teaching, and collaboration enable employees (mentees) to improve their } \\
\text { skills. }\end{array}$ \\
\hline $\mathrm{I}-47$ & My organization provides coaching, mentoring, and feedback so the employees feel valued and important. \\
\hline $\mathrm{I}-48$ & Talent review and feedback processes are standardized in my organization. \\
\hline $\mathrm{I}-49$ & $\begin{array}{l}\text { My organization has clear job descriptions, so the skills, abilities, and experience needed from a new employee } \\
\text { are known. }\end{array}$ \\
\hline $\mathrm{I}-50$ & My organization has created a talent pool. \\
\hline
\end{tabular}

The basic premise was that the 50 analyzed HRM practices could be explained by a smaller number of common latent variables, to which we referred as the dimensions of human resource management practices. Thus, the aim of the study was to identify the dimensions of human resource management practices as common factors. Therefore, 
we chose factor analysis as the basic starting methodology for examining respondents' views/attitudes on human resource management practices. The method of extraction of common latent variables was not chosen at random but on the basis of two basic indicators: the maximum value of the explained variability and the minimum number of meaningful factors/dimensions. Given the recommendations, e.g. Meloun and Militký [49] for the minimum value of the explained variability, only the PCA method met the condition of at least 70\% (MINRES $=52.173 \%$, Maximum likelihood factors $=47.992 \%$, Centroid method $=53.004 \%$, Principal axis method $=44.365 \%$ ). The subsequent rotation of factors/dimensions of human resource management practices was evaluated on the basis of the values of the residual correlation matrix. Only when using the Varimax rotation did the residual correlations reach less than 0.1 . For the other methods of factor analysis rotation, the values of residual correlations were in the range of $0.1-0.4$, which is not satisfactory from the point of view of applicability (Table 2).

Table 2. Percentage of variability of items of HRM practices.

\begin{tabular}{lll}
\hline \multicolumn{1}{c}{ Factors } & \multicolumn{1}{c}{ Percentage of Item Variability } & Total Variance Percentage \\
\hline & I-5 (31.12\%); I-17 (29.34\%); & $27.72 \%$ \\
Information Sharing (1) & I-29 (29.30\%); I-30 (45.97\%); I-45 (26.20\%); & \\
& I-46 (49.79\%); I-47 (41.98\%); I-48 (47.75\%); & $6.38 \%$ \\
Employee Remuneration (2) & I-49 (58.62\%) & $5.54 \%$ \\
Career Growth (3) & I-6 (63.38\%); I-7 (66.44\%); I-8(63.78\%); I-39 & $4.45 \%$ \\
Employee Training and Development (4) & I-31.76\%) & $4.09 \%$ \\
& I-14 (44.47\%); I-15 (43.88\%) & $3.88 \%$ \\
Performance Evaluation System (5) & I-22 (67.24\%); I-23 (56.92\%); I-24 (29.93\%); & $3.54 \%$ \\
Internal Recruitment (6) & I-32 (33.47\%) & $3.25 \%$ \\
Job Certainty (7) & I-4 (62.68\%); I-50 (46.69\%) & $3.14 \%$ \\
Key Competencies (8) & I-16 (71.53\%) & $2.68 \%$ \\
Organizational Responsibility (9) & I-19 (58.30\%); I-26 (33.92\%) & $2.55 \%$ \\
Employee Engagement (10) & I-9 (41.87\%); I-21 (26.60\%); I-36 (47.94\%) & $2.40 \%$ \\
Conditional Certainty (11) & I-25 (37.61\%); I-41 (59.44\%) & $2.24 \%$ \\
Cooperation (12) & I-18 (69.04\%) & $2.11 \%$ \\
Organizational Freedom (13) & I-27 (64.06\%) & \\
Employment/Job Acceptance (14) & I-2 (-28.63\%); I-10 (25.36\%); I-37 (33.44\%) & \\
\hline
\end{tabular}

On the basis of the character of our dataset, the method of the Principal Component Analysis (PCA) was used with the aim of identifying the main factors of HRM practices; the retention of talented employees and the organizational commitment of talented employees. The Kaiser-Mayer-Olkin (KMO) test and Bartlett's Test of Sphericity (Table 3) confirmed the suitability of the data for factor analysis due to the level of significance (sig. 0.000).

Table 3. The results of the data suitability tests for PCA.

\begin{tabular}{cccc}
\hline & Kaiser-Mayer-Olkin Test & \multicolumn{2}{c}{ Bartlett's Test of Sphericity } \\
\hline HRM practices & MS & Value & df \\
\hline Talented em-ployee retention & 0.825 & 3913.203 & 153 \\
\hline Organizational commitment & 0.888 & 4171.235 & 153 \\
\hline
\end{tabular}

By the use of the Principal Component Analysis, 14 factors of the human resource management (HRM) practices were extracted from 50 items, namely: Information Sharing (1); Employee Remuneration (2); Career Growth (3); Employee Training and Development (4); Performance Evaluation System (5); Internal Recruitment (6); Job Certainty (7); Decision- 
making (8); Organizational Responsibility (9); Employee Engagement (10); Conditional Certainty (11); Cooperation (12); Organizational Freedom (13); Employment/Job Acceptance (14). The resulting eigenvalues, which represent the amount of variance accounted for each factor, are presented in Table 4.

Table 4. Eigenvalues of the correlation matrix of HRM practices and related statistics.

\begin{tabular}{|c|c|c|c|c|}
\hline & Eigenvalue & $\begin{array}{l}\% \text { Total } \\
\text { Variance }\end{array}$ & $\begin{array}{l}\text { Cumulative } \\
\text { Eigenvalue }\end{array}$ & $\begin{array}{c}\text { Cumulative } \\
\%\end{array}$ \\
\hline Information Sharing (1) & 13.85944 & 27.71887 & 13.85944 & 27.71887 \\
\hline $\begin{array}{l}\text { Employee } \\
\text { Remuneration (2) }\end{array}$ & 3.18757 & 6.37515 & 17.04701 & 34.09402 \\
\hline Career Growth (3) & 2.76936 & 5.53873 & 19.81637 & 39.63275 \\
\hline $\begin{array}{l}\text { Employee Training and } \\
\text { Development (4) }\end{array}$ & 2.22740 & 4.45480 & 22.04377 & 44.08755 \\
\hline $\begin{array}{l}\text { Performance Evaluation } \\
\text { System (5) }\end{array}$ & 2.04272 & 4.08545 & 24.08650 & 48.17299 \\
\hline Internal Recruitment (6) & 1.94159 & 3.88317 & 26.02808 & 52.05617 \\
\hline Job Certainty (7) & 1.77221 & 3.54442 & 27.80029 & 55.60059 \\
\hline Key Competencies (8) & 1.62523 & 3.25045 & 29.42552 & 58.85104 \\
\hline $\begin{array}{l}\text { Organizational } \\
\text { Responsibility (9) }\end{array}$ & 1.56940 & 3.13879 & 30.99492 & 61.98983 \\
\hline $\begin{array}{l}\text { Employee Engagement } \\
\text { (10) }\end{array}$ & 1.49131 & 2.98263 & 32.48623 & 64.97246 \\
\hline $\begin{array}{l}\text { Conditional Certainty } \\
\text { (11) }\end{array}$ & 1.27913 & 2.55826 & 33.76536 & 67.53072 \\
\hline Cooperation (12) & 1.20462 & 2.40925 & 34.96998 & 69.93996 \\
\hline $\begin{array}{l}\text { Organizational Freedom } \\
\text { (13) }\end{array}$ & 1.12227 & 2.24455 & 36.09225 & 72.18451 \\
\hline $\begin{array}{l}\text { Employment/Job } \\
\text { Acceptance (14) }\end{array}$ & 1.05665 & 2.11330 & 37.14891 & 74.29781 \\
\hline
\end{tabular}

Using the PCA analysis with varimax rotation, the two main factors were extracted within the dimension of talented employees' retention (the first explaining $46.06 \%$ of the variance, and the second explaining $6.65 \%$ of the variance). Subsequently, these factors were named as: Retention of Senior Talent (46.06\%) and Retention of Junior Talent $(6.65 \%)$, based on the items they included. The RST factor contained eight items representing the predictors for retaining senior talents in organizations such as: good retirement opportunities, regularly increasing salary, managerial position within the company, etc. [50]. The RJT factor, which mostly defined young talents, was saturated by 11 items such as: assignment of tasks for which they have competencies in order to gain and strengthen new skills [51]; fulfillment of demanding tasks; an initiative in areas where they still need to improve $[40,41,52,53]$; possessing an excellent level of the self-management; their acceptance as budding leaders within their team; employee recognition, etc. [54].

We can thus conclude that two groups of talented employees (senior and junior) were extracted within this research, which we will take into account within the canonical correlation analysis (Table 5). This conclusion also corresponds with the distribution of the research sample of talented employees based on the number of years worked in the company (66.5\% up to 3 years; $20.46 \%$ from 3 to 5 years; $8.18 \%$ more than 7 years).

Table 5. Eigenvalues of the correlation matrix of talented employees' retention and related statistics.

\begin{tabular}{ccccc}
\hline \multirow{2}{*}{ Factor } & Eigenvalue & $\begin{array}{c}\text { \% Total } \\
\text { Variance }\end{array}$ & $\begin{array}{c}\text { Cumulative } \\
\text { Eigenvalue }\end{array}$ & \multicolumn{2}{c}{$\begin{array}{c}\text { Cumulative } \\
\%\end{array}$} \\
\hline RST & 8.2921 & 46.0673 & 8.2921 & 46.06 \\
RJT & 1.1976 & 6.6537 & 9.4898 & 52.72 \\
\hline
\end{tabular}


The level of the organizational commitment, engagement, and loyalty of employees at the organizational level was analyzed by the questionnaire for organizational commitment developed by Mowday, Steers and Porter [28]. By the application of the PCA analysis, one factor which contained 9 items was extracted (Table 6), named Organizational Commitment Factor (3).

Table 6. Eigenvalues of the correlation matrix of organizational commitment and related statistics.

\begin{tabular}{ccccc}
\hline Factor & Eigenvalue & $\begin{array}{c}\text { \% Total } \\
\text { Variance }\end{array}$ & $\begin{array}{c}\text { Cumulative } \\
\text { Eigenvalue }\end{array}$ & $\begin{array}{c}\text { Cumulative } \\
\%\end{array}$ \\
\hline $\begin{array}{c}\text { Organizational } \\
\text { Commitment }\end{array}$ & 4.78595 & 31.90638 & 4.78595 & 44.90639 \\
\hline
\end{tabular}

\section{Canonical correlation analysis}

The canonical correlation analysis was used to examine the significance of the relationship between the set of factors of HRM practices and these dependent variables: two factors of talented employees' retention (RST and RJT), and the factor of organizational commitment.

Table 7 shows a summary of the canonical analysis results. The set of canonical variables on the left represents independent variables - the factors of HRM practices (14), and the set on the right represents dependent variables (two factors of talented employees' retention and the factor of organizational commitment).

Table 7. Canonical correlation analysis scheme.

\begin{tabular}{|c|c|c|}
\hline & \multicolumn{2}{|c|}{ Canonical R: 0.88412; Chi2(56) = 930; $24 p=0.0000$} \\
\hline & Left Set & Right Set \\
\hline Number of variables & 14 & 3 \\
\hline Variance & $28.7 \%$ & $100.00 \%$ \\
\hline Total $\mathrm{r}$ & $11.07 \%$ & $44.36 \%$ \\
\hline $\begin{array}{l}\text { Canonical Variables } \\
1\end{array}$ & Information Sharing & \\
\hline 2 & Employee Remuneration & RST (1) \\
\hline 3 & Career Growth & RJT (2) \\
\hline 4 & $\begin{array}{l}\text { Employee Training and } \\
\text { Development }\end{array}$ & $\begin{array}{c}\text { Organizational commitment } \\
\text { (3) }\end{array}$ \\
\hline 5 & $\begin{array}{c}\text { Performance Evaluation } \\
\text { System }\end{array}$ & \\
\hline 6 & Internal Recruitment & \\
\hline 7 & Job Certainty & \\
\hline 8 & Key Competencies & \\
\hline 9 & Organizational Responsibility & \\
\hline 10 & Employee Engagement & \\
\hline 11 & Conditional Certainty & \\
\hline 12 & Cooperation & \\
\hline 13 & Organizational Freedom & \\
\hline 14 & Employment/Job Acceptance & \\
\hline
\end{tabular}

The results of the canonical $\mathrm{R}(0.88 ; p<0.05)$ in Table 5 indicate a statistically significant dependence between the analyzed factors. This coefficient showed as the largest possible correlation, so it could be considered as a measure of the overall correlation between these two sets of canonical variables. If the value of this coefficient were low, it would indicate the weak relationship between the canonical variables and it would not be considered significant.

Authors Mey, Poisat, and Stindt [55] support these results with their research that aimed at identifying leadership types of behavior that affect the retention of talented employees. The study revealed that retaining talented employees requires leaders who 
provide them a sense of belonging, respect, support for personal and career growth, with an emphasis on business practices. Gurusinghe, Arachige, and Dayarathna [56] prioritized the digitization and predictive analysis of human resources in the company for the effective management of skilled employees. A predictive analysis of human resources completes the best HRM practices in the company and strategic business decisions while gaining a competitive advantage. The authors highlighted organizations which, in conjunction with HRM practices, tended to be competitive through the modelling expected to avoid turnover and attract new talented employees.

Table 8 summarizes the correlations of the left and the right sets of canonical variables entering the canonical correlation analysis. Primarily, it has to be noted that there is no general rule that would determine the appropriate size of the canonical correlation. For this reason, the equivalent of the canonical correlation analysis $(k=0.20)$ was taken into account when assessing the statistical significance of relationships between factors, which was considered to be a priority while identifying significant correlations and verifying research hypotheses. Based on the results showed in Table 2 , supported by recent studies and research, Hypothesis 1 was confirmed and thus there is a statistically significant relationship between the set of HRM practices and the retention of talented employees in organizations.

Table 8. Results of the canonical correlation.

\begin{tabular}{cccc}
\hline HRM Practice Factors & RST (1) & RJT (2) & $\begin{array}{c}\text { Organizational } \\
\text { Commitment (3) }\end{array}$ \\
\hline $\begin{array}{c}\text { Information Sharing (1) } \\
\text { Employee Remuneration (2) }\end{array}$ & 0.295137 & 0.319065 & 0.405972 \\
$\quad$ Career Growth (3) & 0.095230 & -0.074742 & 0.157404 \\
Employee Training and & 0.222735 & 0.040492 & 0.095746 \\
$\quad$ Development (4) & 0.229400 & 0.01992 & 0.30467 \\
Performance Evaluation & 0.256884 & 0.189234 & 0.080887 \\
$\quad$ System (5) & 0.121256 & 0.072089 & 0.360391 \\
Internal Recruitment (6) & 0.071552 & -0.116912 & -0.059211 \\
$\quad$ Job Certainty (7) & 0.181969 & 0.007577 & 0.249552 \\
Key Competencies (8) & 0.076797 & -0.052292 \\
$\quad$ Organizational & 0.010472 & 0.261345 & 0.039568 \\
$\quad$ Responsibility (9) & 0.201544 & 0.305293 & 0.345312 \\
Employee Engagement (10) & 0.235177 & 0.165317 & 0.112546 \\
Conditional Certainty (11) & 0.138272 & 0.124503 & 0.185548 \\
$\quad$ Cooperation (12) & 0.124664 & 0.114965 & 0.147517 \\
Organizational Freedom (13) & & & \\
Employment Acceptance (14) & & & \\
\hline
\end{tabular}

The statistically significant relationships were identified within the selected HRM practices and retention of talented employees:

HRM practice (1)—Information sharing; RST/RJT factors (0.295137/0.319065): The factor considering information sharing is based on the transfer and sharing of information between employees. The RJT factor is considered to be the most relevant factor in this study, especially in these impulsive times of the COVID-19 pandemic, what is also supported by the studies of Pahwa and Rangnekar [57]; Collings, McMackin, Nyberg, and Wright [58] focused on the retention of talented employees in the pandemic era. We believe that young talents complement and strengthen the pillars of the organizational structure of the company already in the early stages of strategic planning. Initial/junior talent is formed by the regular contribution of current information and the assignment of tasks, as the company's management believes in rooting their current competencies and skills while gaining new experiences. On this basis, companies are interested in their workforce and they are proactive in the areas where they feel the need to be further improved. Through these information-sharing tasks, the junior talents are provided a good basis for their self-management, which is an important skill for their future career growth and leadership 
function. The results of other studies, as those made by Rice, Young, and Sharidan [59] or by $\mathrm{Ng}$ and Clercq [60], examined young talented employees in relation to their selfmanagement and the prevention of turnover, are in line with this view.

HRM practice factor (4) -Employee training and development; RST factor (0.222735): This statistically significant relationship can be considered a basis for retaining talented employees. Based on this relationship, we can consider senior talented employees as those who are characterized by a higher degree of willingness to learn. This relationship confirms the importance of developing the skills and competencies of senior talented employees, which can be beneficial in the education and development of young talents through the transfer of the seniors' skills and knowledge.

HRM practice factor (5)—Performance evaluation system; RST factor (0.229400): This relationship confirms the importance of senior talented employees' participation in decisionmaking processes, employee performance evaluation, and cooperation with managers during the creation of performance evaluation models in the company due to their initiative and experience in the company. The performance evaluation systems and models are mostly subjective and created based on managerial experience because every company has its own specific characteristics and needs.

HRM practice factor (6)-Internal recruitment; RST factor (0.256884): Senior talented employees have a great potential for career growth, initiative, and the use of every opportunity to take responsibility for key competencies in the company. During the decisionmaking process regarding the internal employees' promotion and their salary increase, $\mathrm{HR}$ managers primarily take into account talented employees who have a higher predisposition for career growth as compared to other ordinal employees applying for the promotion.

HRM practice (10) —Employee engagement; RJT factor (2) (0.261345): This relationship expresses the level of employee engagement conditioned by their work team and the performance evaluation system. This relationship underlines the responsibility and effectiveness of HRM for such employees, who are firmly rooted at the very beginning of performing important tasks, where self-management and employee initiative are obvious [61]. Employee engagement, which is conditioned by the work team and the performance evaluation system for young talented employees, also confirms the interest of the management and the HRM division in maintaining talented employees and further monitoring their growth process with the mentioned variables.

HRM practice factor (11)—Conditional certainty; RST/RJT factors (0.201544/0.305293): In order to retain senior talented employees in the company, it is necessary to provide them with suitable and stable conditions so that they have a reason to be loyal to company until their retirement. A statistically significant relationship with the RJT factor was also proved. Conditional certainty represents long-term job security not only for senior talented employees, but also for young talents. Such employees, who show they potential talent in the work process, represent the next generation seeking security in their jobs. On the basis of social reciprocity, young employees try to put their initiative and talent into the company, while they expect the long-term security and stability of their job position in the company.

HRM practice factor (12)—Cooperation; factor RST (1) (0.235177): This statistically significant relationship confirms the importance of participation and cooperation in the decision-making process in the company for retaining senior talented employees. If a company wants to retain senior talented employees, it is very important to take their opinion into account.

The second hypothesis $(\mathrm{H} 2)$ was confirmed on the basis of the results of the canonical correlation analysis. The results supported the existence of a significant relationship between HRM practices and the organizational commitment of employees:

HRM practice factor-Information sharing; Organizational commitment (3) (0.405972): This relationship is defined through open communication with the company's management and the willingness of employees to receive information so they can use it to their advantage in order to increase their work performance. This fact underlines the importance of 
employee values, where values such as commitment and loyalty to the company are required. Based on the shared information and the level of organizational commitment, the employees are willing to accept any type of task so they can participate in the work process. Such behavior is reflected in their work performance and persistence in the company even during the crisis. This view is also supported by the results of another research works focused on the organizational commitment of employees during unstable periods in the company and the impact of turnover, for example, Aguinis and Burgi-Tian's research [62] and Im, Kim, and Miao's research [63].

HRM practice factor (4) -Employee Training and Development; Organizational commitment (3) (0.304670): This relationship confirms the special need to educate employees who are dedicated and loyal to their company, which is in line with the conclusions of Bailey et al. [64]. When the values of employees and the values of the company coincide, the need for education, growth, and development of those employees is desirable because they are interested in the fate and future of the company. In the current circumstances (during the economic crisis), they do not plan to retire; on the contrary, they will remain because the company finds the most skilled workers among them.

HRM practice factor (6) - Internal recruitment; Organizational commitment (3) (0.36091): This relationship is defined by the recruitment of the employees from the internal environment of the company based on the degree of their organizational commitment. This relationship confirms the need to monitor changes in employee engagement and commitment, which are reflected in their work performance. The management can identify their level of organizational commitment, which facilitates the process of internal recruitment of employees for promotion by monitoring the career growth of employees, their participation in the assigned tasks, and a ratio of task acceptance [65].

HRM practice Factor (8)-Key competencies; Organizational commitment (3) (0.249552): The importance of this relationship is underlined by decision-making, especially during crisis situations, with an emphasis on the organizational commitment of talented employees. It reflects on the current pandemic situation in the world. Organizations need to maintain and strengthen market stability against adverse conditions in order to make a profit [66]. This statistically significant relationship has shown that nowadays, some companies reciprocate employees' show of loyalty by remaining in their job and their job position, as confirmed by Isah et al. [67] or Slatten et al. [68].

HRM practice factor (11) - Conditional certainty; Organizational commitment (3) (0.345312): The significant relationship between these factors is characterized by job certainty in the long run. When the employees demonstrate a certain degree of organizational commitment, the company repays their commitment by retaining them because of their skills, competencies, and initiative, which are more than beneficial to the company [69].

\section{Discussion}

Based on the results of our research, we can state that the more resources (human, financial, etc.) companies are willing to invest in talented employees, the higher the performance they can expect from them in the future; this is confirmed by other authors such as Romans and Larder [70], Davenport, Harris, and Shapiro [71]. As a part of our research, we found a suitable set of HRM practices with an emphasis on talent management, which directly affects the performance of talented employees towards organizations and reduce their fluctuation. Some authors highlighted the importance of the performance systems in companies which also take into account talented employees. This type of integrated performance management system mainly targets talented employees who achieve observably higher performance compared to the other average employees. This statement is also confirmed by a study of the correlation between talented workers and the level of performance in companies from Boxall and Macky [72] and Kontoghiorghes and Frangou [73].

The social exchange theory states that people tend to reciprocate the benefits provided by other social entities, whether individuals or organizations, but the degree of this reciprocation may vary depending on the perception of the benefit by the individual and the level 
of communication which mediates this benefit [21]. This conditional aspect of the social exchange theory can lead talented employees to have differing perceptions of some HRM practices aimed at building their commitment and performance, leading to different levels of performance for these workers. The principle of the theory of social exchange is based on the principle of reciprocity, i.e., if a talented worker finds that a certain HRM practice is in his favor, he will try to repay it with his higher performance and commitment in relation to the organization, which will ultimately be reflected in his persistence and performance. Based on this, we conclude that the relationship between practices in the organization and the tendency to leave the organization is mediated through talented employees, HRM practices, and organizational commitment.

Within this study, the importance of HRM practices and their impact on the retention of talented employees and their organizational commitment were proven. The results of this research underlines the importance of their implementation in practice.

The research revealed several best practices in HRM (Information Sharing, Employee Training and Development, Performance Evaluation System, Internal Recruitment, Cooperation, etc.). If we take a closer look at these practices, we will find a multiple linear dependence of statistical relations. In the BPS model, information sharing is considered to be the basis of success; thanks to this information, senior and junior talented employees complete and strengthen organizational commitment for the entire company. Bowman and Spence [74] share this view by investigating fluctuations due to lack of communication.

\section{Conclusions}

To realize and implement organizational goals, organizations need employees who have a high potential and a clear vision for the future. The current demographic, social, and economic situation in Europe is reflected in the shortage of talented workers in the labor market. Companies and organizations realize that in the war for talent, those who understand that talent management is key and then invest sufficient attention, time, and money in it will succeed.

Human resource management practices are constantly evolving in organizations to meet the best available standards and norms. The situation associated with the COVID-19 pandemic has also made a significant contribution to changes and progress in HRM practices. The relationship between HRM practices and the intention of talented employees to remain in the organization is mediated through organizational commitment. The principle of the social exchange theory is based on the principle of reciprocity, i.e., if a talented employee finds that a certain HRM practice is in his/her favor, he/she will try to return it to the organization through its performance and dedication, which will be reflected in its performance and intent to remain in the organization.

Based on the results of this research, the concept of talent management in organizations is directly connected with human resource management and its practices. The results of our study provide a deeper understanding of how a set of identified human resource management practices can contribute to the retention and commitment of talented employees. The research revealed several best practices in human resource management (Information Sharing, Employee Training and Development, Performance Evaluation System, Internal Recruitment, Conditional Assurance, Cooperation, etc.). If we take a closer look at these practices, we will find a multiple linear dependence of statistical relationships.

Research has revealed that many organizations implement talent management processes, procedures, and practices to a limited extent, often due to insufficient knowledge of the issue. Surprisingly, when collecting data (since the research was focused on that group of employees who were considered to be organizational talents), we found that identifying talents is one of the pitfalls of talent management in organizations in Slovakia. Similar to other studies, ours has some limitations that should to be considered in interpreting the results of the presented study. The present results are based on a sample of talented employees working in medium-sized and large organizations (with more than 50 employees). The focus on medium and large organizations was based on the assumption that 
larger companies are more likely to implement talent management. The sampling in this study might limit the generalizability of the findings. Participants were predominantly represented by employees designated and selected by managers as "talents". We consider the "black box" in the field of identifying talented employees to be one of the limits of research. Organizations often mistakenly and automatically combine high performance with high potential. Other organizations, on the other hand, do not approach it analytically but rely on the instincts or observations of managers to identify employees with potential. Future research should be focused on the mentioned "black box" mechanism of identifying talented employees within organizations.

Author Contributions: Conceptualization, M.V., V.A.T. and V.Š.; methodology, M.V. and J.T.; software and validation, M.V.; formal analysis, V.Š., M.H. and J.T.; investigation, J.T. and M.V.; resources, M.V., V.A.T., V.Š. and M.H.; data curation, M.V.; writing—original draft preparation, review, and editing, M.V., V.A.T. and V.Š.; visualization, M.V.; supervision, J.T. and V.A.T.; project administration and funding acquisition V.A.T. and M.H. All authors have read and agreed to the published version of the manuscript.

Funding: This research was funded by Vedecká Grantová Agentúra MŠVVaŠ SR a SAV (VEGA) and Kultúrna a edukačná grantová agentúra MŠVVaŠ SR (KEGA).

Institutional Review Board Statement: Not applicable.

Informed Consent Statement: Informed: Consent was obtained from all subjects involved in the study.

Data Availability Statement: Data available on request due to restrictions, e.g., privacy or ethical. The data presented in this study are available on request from the corresponding author. The data are not publicly available due to the GDPR.

Acknowledgments: This research is one of the partial outputs under the scientific research grants 1/0237/19-VEGA: Research on the Impact of Human Resource Practices on Organizational Commitment and Retention of Talented and High-Performing Employees, and 012PU-4/2019_KEGA: Elaboration of Didactic Materials for the Newly Introduced Subject “Talent Management".

Conflicts of Interest: The authors declare no conflict of interest.

\section{References}

1. Cappelli, P. Talent management for the twenty-first century. Harv. Bus. Rev. 2008, 86, 74-81. [PubMed]

2. Chartered Institute of Personnel and Development (CIPD). Talent management: Understand the Changing Context and Benefits of Talent Management, and the Key Features of a Talent Management Strategy. Available online: https://www.cipd.co.uk/ knowledge/strategy/resourcing/talent-factsheet (accessed on 25 October 2021).

3. Mitchell, T.; Lee, T. The unfolding model of voluntary turnover and job embeddedness: Foundations for a comprehensive theory of attachment. Res. Organ. Behav. 2001, 23, 189-246. [CrossRef]

4. Green, M. Learning's Role in Integrated Talent Management. T+D Magazine. 13 May 2011. Available online: https://www.td. $\mathrm{org} /$ magazines/td-magazine/learnings-role-in-integrated-talent-management (accessed on 25 October 2021).

5. Kumar, S. The impact of talent management practices on employee turnover and retention intentions. Glob. Bus. Organ. Excel. 2021, in press. [CrossRef]

6. Haldorai, K.; Kim, W.; Pillai, S.; Park, T.; Balasubramanian, K. Factors affecting hotel employees' attrition and turnover: Application of pull-push-mooring framework. Int. J. Hosp. Manag. 2019, 83, 46-55. [CrossRef]

7. Mutanga, J.; Kaisara, G.; Yakobi, K.; Atiku, S. Exploring push and pull factors for talent development and retention: Implications for practice. Dev. Learn. Organ Int. J. 2021, 35, 1-3. [CrossRef]

8. Al Mheiri, S.; Jabeen, F.; Abdallah, S. Inhibitors of Talent Retention in UAE Public Healthcare. Int. J. Bus. Soci. 2021, 22, 74-101. [CrossRef]

9. Pfeffer, J. The Human Equation: Building Profits by Putting People First; Harvard Business School Press: Boston, MA, USA, 1998; ISBN 0-87584-841-9.

10. Miao, R.; Lu, L.; Cao, Y.; Du, Q. The High-Performance Work System, Employee Voice, and Innovative Behavior: The Moderating Role of Psychological Safety. Int. J. Environ. Res. Public Health 2020, 17, 1150. [CrossRef]

11. Iqbal, S.; Moleiro Martins, J.; Nuno Mata, M.; Naz, S.; Akhtar, S.; Abreu, A. Linking Entrepreneurial Orientation with Innovation Performance in SMEs; the Role of Organizational Commitment and Transformational Leadership Using Smart PLS-SEM. Sustainability 2021, 13, 4361. [CrossRef] 
12. Kossivi, B.; Xu, M.; Kalgora, B. Study on Determining Factors of Employee Retention. Open J. Soc. Sci. 2016, 04, 261-268. [CrossRef]

13. Knight, D.; Becan, J.; Flynn, P. The Impact of Staff Turnover on Workplace Demands and Coworker Relationships. Counselor 2013, 14, 20-23.

14. Potgieter, I. Personal Attributes Framework for Talent Retention. In Psychology of Retention: Theory, Research and Practice; Coetzee, M., Potgieter, I.L., Ferreira, N., Eds.; Springer: Cham, Switzerland, 2018; pp. 183-201. ISBN 978-3-319-98919-8.

15. Boonsiritomachai, W.; Sud-On, P. The moderation effect of work engagement on entrepreneurial attitude and organizational commitment: Evidence from Thailand's entry-level employees during the COVID-19 pandemic. Asia-Pacific J. Bus. Adm. 2021. ahead-of-print. [CrossRef]

16. Buchanan, B. Building organizational commitment: The socialization of managers in work organizations. Admin. Sci. Quart. 1974, 19, 533-546.

17. Lee, S. An empirical analysis of organizational identification. Acad. Manag. J. 1971, 14, 213-226.

18. Yousef, D. Validating the dimensionality of Porter et al.'s measurement of organizational commitment in a non-Western culture setting. Int. J. Hum. Res. Manag. 2003, 14, 1067-1079.

19. Allen, N.; Meyer, J. Affective, Continuance, and Normative Commitment to the Organization: An Examination of Construct Validity. J. Vocat. Behav. 1996, 49, 252-276. [CrossRef]

20. Liu, X.; Deng, J. Development of Organizational Commitment Based on the Social Exchange Theory. In Proceedings of the 2011 International Conference on Management and Service Science, Wuhan, China, 12-14 August 2011; pp. 1-6. [CrossRef]

21. Eisenberger, R.; Huntington, R.; Hutchison, S.; Sowa, D. Perceived organizational support. J. App. Psychol. 1986, 71, 500-507. [CrossRef]

22. Kwon, K.; Bae, J.; Lawler, J. High Commitment HR Practices and Top Performers. Manag. Int. Rev. 2010, 50, 57-80. [CrossRef]

23. Parveen, K.; Hussain, K.; Afzal, M.; Gilani, S. Determining the association of high-commitment human resource practices with nurses' compassionate care behaviour: A cross-sectional investigation. J. Nurs. Manag. 2019, 28, 120-129. [CrossRef] [PubMed]

24. Rubel, M.; Rimi, N.; Yusliza, M.; Kee, D. High commitment human resource management practices and employee service behaviour: Trust in management as mediator. IIMB Manag. Rev. 2018, 30, 316-329. [CrossRef]

25. Singh, K.; Onahring, B. Entrepreneurial intention, job satisfaction and organisation commitment-Construct of a research model through literature review. J. Glob. Entrep. Res. 2019, 9, 16. [CrossRef]

26. Greenberg, J.; Baron, R. Behavior in Organizations: Understanding and Managing the Human Side of Work, 9th ed.; Pearson Prentice Hall: Upper Saddle River, NJ, USA, 2008; ISBN 9780136006879.

27. Becker, H. Notes on the Concept of Commitment. Am. J. Soc. 1960, 66, 32-40. [CrossRef]

28. Mowday, R.; Steers, R.; Porter, L. The measurement of organizational commitment. J. Vocat. Behav. 1979, 14, 224-247. [CrossRef]

29. Mathieu, J.; Zajac, D. A review and meta-analysis of the antecedents, correlates, and consequences of organizational commitment. Psychol. Bullet. 1990, 108, 171-194. [CrossRef]

30. Meyer, J.; Allen, N. A three-component conceptualization of organizational commitment. Hum. Res. Manag. Rev. 1991, 1, 61-89. [CrossRef]

31. Rupp, D.; Cropanzano, R. The mediating effects of social exchange relationships in predicting workplace outcomes from multifoci organizational justice. Organ. Behav. Hum. Decis. Process. 2002, 89, 925-946. [CrossRef]

32. Takahashi, C.; Yamagishi, T.; Liu, J.; Wang, F.; Lin, Y.; Yu, S. The intercultural trust paradigm: Studying joint cultural interaction and social exchange in real time over the Internet. Int. J. Intercult. Relat. 2008, 32, 215-228. [CrossRef]

33. Rhoades, L.; Eisenberger, R.; Armeli, S. Affective commitment to the organization: The contribution of perceived organizational support. J. Appl. Psychol. 2001, 86, 825-836. [CrossRef]

34. Mottaz, C. Determinants of Organizational Commitment. Hum. Relat. 1988, 41, 467-482. [CrossRef]

35. Meyer, J.; Allen, N. Commitment in the Workplace: Theory, Research, and Application; SAGE Publications, Inc.: Thousand Oaks, CA, USA, 1997; ISBN 9780761901051.

36. Park, S.; McLean, G.; Yang, B. Impact of managerial coaching skills on employee commitment: The role of personal learning. Eur. J. Train. Dev. 2020, 45, 814-831. [CrossRef]

37. Ji, S.; Jan, I. Antecedents and Consequences of Frontline Employee's Trust-in-Supervisor and Trust-in-Coworker. Sustainability 2020, 12, 716. [CrossRef]

38. Macky, K.; D'Amato, A.; Herzfeldt, R. Learning orientation, organizational commitment and talent retention across generations. J. Manag. Psychol. 2008, 23, 929-953.

39. Revuelto-Taboada, L.; Canet-Giner, M.; Balbastre-Benavent, F. High-Commitment Work Practices and the Social Responsibility Issue: Interaction and Benefits. Sustainability 2021, 13, 459. [CrossRef]

40. Delery, J.; Doty, D. Modes of Theorizing in Strategic Human Resource Management: Tests of Universalistic, Contingency, and Configurational Performance Predictions. Acade. Manag. J. 1996, 39, 802-835. [CrossRef]

41. Redman, T.; Matthews, B. Service quality and human resource management: A review and research agenda. Person. Rev. 1998, 27, 57-77. [CrossRef]

42. Newstrom, J. Organizational Behavior Human Behavior at Work, 11th ed.; McGraw-Hill: New York, NY, USA, 2002.

43. Judge, T. Dispositional Effects on Job and Life Satisfaction: The Role of Core Evaluations. J. App. Psychol. 1998, 83, 17-34. [CrossRef] [PubMed] 
44. Lindsey, G.; Kleiner, B. Nurse residency program: An effective tool for recruitment and retention. J. Health Care Financ. 2005, 31, 25-32.

45. Martín-Alcázar, F.; Romero-Fernández, P.; Sánchez-Gardey, G. Strategic human resource management: Integrating the universalistic, contingent, configurational and contextual perspectives. Int. J. Hum. Res. Manag. 2005, 16, 633-659. [CrossRef]

46. Milkovich, G.T.; Gerhart, B.; Hannon, J. The effects of research and development intensity on managerial compensation in large organizations. J. High Technol. Manag. Res. 1991, 2, 133-150. [CrossRef]

47. Sojka, L. Praktiky Riadenia L'udských Zdrojov z Hl'adiska Hodnotenia ich Vplyvu na Výstupy Organizácie, 1st ed.; Bookman: Prešov, Slovakia, 2016; ISBN 978-80-8165-165-6.

48. Marchington, M.; Grugulis, I. 'Best practice' human resource management: Perfect opportunity or dangerous illusion? Int. J. Hum. Resour. Manag. 2000, 11, 1104-1124. [CrossRef]

49. Meloun, M.; Militký, J. Kompendium Statistického Zpracování Dat: Metody a Řešené Úlohy Včetně CD, 1st ed.; Academia: Praha, Czech Republic, 2002; ISBN 80-200-1008-4.

50. Filimonau, V.; Derqui, B.; Matute, J. The COVID-19 pandemic and organisational commitment of senior hotel managers. Int. J. Hosp. Manag. 2020, 91, 102659. [CrossRef]

51. Oliver, D. An Expectation of Continued Success: The Work Attitudes of Generation Y. Lab. Indust. J. Soc. Eco. Relat. Work 2013, 17, 61-84. [CrossRef]

52. Luscombe, J.; Lewis, I.; Biggs, H. Essential elements for recruitment and retention: Generation Y. Educ. Train. 2013, 55, 272-290. [CrossRef]

53. Terjesen, S.; Vinnicombe, S.; Freeman, C. Attracting Generation Y graduates. Car. Dev. Int. 2007, 12, 504-522. [CrossRef]

54. van Scheijndel, R. Recruiting Young Talent in Deep-Tech Venture Building Design of an Evidence-Based Framework to Recruit Young Talent in New Deep-Tech Venture Team Formation. Master's Thesis, Eindhoven University of Technology, Eindhoven, The Netherlands, 2020.

55. Mey, M.R.; Poisat, P.; Stindt, C. The influence of leadership behaviours on talent retention: An empirical study. SA J. Hum. Resour. Manag. 2021, 19, e1-e9. [CrossRef]

56. Gurusinghe, R.N.; Arachchige, B.J.H.; Dayarathna, D. Predictive HR analytics and talent management: A conceptual framework. J. Manag. Anal. 2021, 8, 195-221. [CrossRef]

57. Pahwa, M.; Rangneka, S. Retaining the Key Talent through Empowerment in COVID-19. Ind. J. Train. Dev. 2020, 50, 51-59.

58. Collings, D.; McMackin, J.; Nyberg, A.; Wright, P. Strategic Human Resource Management and COVID-19: Emerging Challenges and Research Opportunities. J. Manag. Stud. 2021, 58, 1378-1382. [CrossRef]

59. Rice, D.B.; Young, N.C.J.; Sheridan, S. Improving employee emotional and behavioral investments through the trickle-down effect of organizational inclusiveness and the role of moral supervisors. J. Bus. Psychol. 2020, 36, 267-282. [CrossRef]

60. Ng, P.; Clercq, D. Explaining the entrepreneurial intentions of employees: The roles of societal norms, work-related creativity and personal resources. Int. Small Bus. J. Res. Entrep. 2021, 38, 732-754. [CrossRef]

61. Ishfaq, A.; Rabia, A.; Siti Zaleha, A. Employees' task performance and propensity to take charge the role of LMX and leader's task orientation. J. Manag. Dev. 2021, 40, 224-239.

62. Aguinis, H.; Burgi-Tian, J. Measuring performance during crises and beyond: The Performance Promoter Score. Bus. Horiz. 2020, 64, 149-160. [CrossRef] [PubMed]

63. Im, J.; Kim, H.; Miao, L. CEO letters: Hospitality corporate narratives during the COVID-19 pandemic. Int. J. Hosp. Manag. 2020, 92, 102701. [CrossRef] [PubMed]

64. Bailey, A.; Govia, I.; McKenzie, J.; Richards, S.; Coleman, S.; Tulloch-Reid, M.K.; Ragin, C.; Ashing, K. Staff and participant perceptions of optimal recruitment and retention strategies for biomedical cohort studies in the Caribbean. Cancer Causes Control. 2021, 32, 849-857. [CrossRef]

65. Govand, A.; Nabaz Nawzad, A. The impact of Human resource management practice on Organizational performance. Int. J. Eng. Busi. Manag. 2021, 5, 35-47.

66. Yousf, A.; Khurshid, S. Impact of Employer Branding on Employee Commitment: Employee Engagement as a Mediator. Vis. J. Bus. Perspect. 2021. [CrossRef]

67. Isah, S.; Ibrahim, R.; Shehu, M.; Gwadabe, U. The Mediating Effect of Work Engagement in the Link between Affective Commitment and Employee Competence in Nigeria Universal Basic Education system. Int. Sch. J. Art. Soci. Sci. Res. 2021, 3 , 285-305.

68. Slatten, L.A.; Bendickson, J.S.; Diamond, M.; McDowell, W.C. Staffing of small nonprofit organizations: A model for retaining employees. J. Innov. Knowl. 2020, 6, 50-57. [CrossRef]

69. Kryscynski, D. Firm-Specific Worker Incentives, Employee Retention, and Wage-Tenure Slopes. Organ. Sci. 2021, 32, $352-375$. [CrossRef]

70. Romans, J.; Lardner, L. Integrated talent management at BD Japan: How a holistic approach to talent management built a high performance culture. Strat. HR Rev. 2005, 4, 16-19. [CrossRef]

71. Davenport, T.H.; Harris, J.; Shapiro, J. Competing on talent analytics. Harv. Bus. Rev. 2010, 88, 52-58.

72. Boxall, P.; Macky, K. Research and theory on high-performance work systems: Progressing the high-involvement stream. Hum. Resour. Manag. J. 2008, 19, 3-23. [CrossRef] 
73. Kontoghiorghes, C.; Frangou, K. The Association Between Talent Retention, Antecedent Factors, and Consequent Organizational Performance. SAM Adv. Manag. J. 2009, 74, 29-36.

74. Bowman, N.; Spence, P. Challenges and Best Practices Associated with Sharing Research Materials and Research Data for Communication Scholars. Commun. Stud. 2020, 71, 708-716. [CrossRef] 